\title{
Perbedaan Kualitas Soft Skill Mahasiswa Sebelum dan Sesudah Pelatihan Manajemen Diri
}

\author{
Erni Hernawati, ${ }^{1}$ Ponpon S. Idjradinata, ${ }^{2}$ Ike Husen, ${ }^{3}$ Farid Husin, ${ }^{4}$ Firman F. Wirakusumah, ${ }^{5}$ M. Nurhalim \\ Shahib, ${ }^{6}$ Dewi M.D. Herawati ${ }^{7}$ \\ ${ }^{1}$ Mahasiswa Program Studi Magister Kebidanan Fakultas Kedokteran Universitas Padjadjaran \\ ${ }^{2}$ Departemen Ilmu Kesehatan Anak Fakultas Kedokteran Universitas Padjadjaran \\ ${ }^{3}$ Departemen Farmakologi dan Terapi Fakultas Kedokteran Universitas Padjadjaran \\ ${ }^{4}$ Departemen Epidemiologi dan Biostatistika Fakultas Kedokteran Universitas Padjadjaran \\ ${ }^{5}$ Departemen Obstetri dan Ginekologi Fakultas Kedokteran Universitas Padjadjaran \\ ${ }^{6}$ Departemen Biokimia Fakultas Kedokteran Universitas Padjadjaran \\ ${ }^{7}$ Departemen Ilmu Kesehatan Masyarakat Fakultas Kedokteran Universitas Padjadjaran
}

\begin{abstract}
Abstrak
Institusi pendidikan bidan bertujuan mencetak lulusan bidan yang memiliki kemampuan baik secara akademik maupun non akademik dan siap kerja. Berbagai upaya yang dilakukan untuk meningkatkan soft skill mahasiswa hingga saat ini belum memuaskan. Salah satu cara meningkatkan kualitas soft skill mahasiswa yaitu dengan pelatihan manajemen diri. Tujuan penelitian ini untuk menganalisis perbedaan kualitas soft skill dari aspek komunikasi, kepemimpinan, dan etika mahasiswa sebelum dan sesudah diberikan pelatihan manajemen diri. Penelitian ini menggunakan metode eksperimental dengan desain one group pre-test and post-test design. Populasi penelitian mahasiswa Program Studi DIII Kebidanan yang teridentifikasi nilai soft skill rendah berjumlah 47 orang. Teknik pengambilan sampel dengan total sampling. Pengukuran soft skill menggunakan kuesioner. Hasil analisis penelitian kualitas soft skill mahasiswa sebelum dan sesudah diberikan pelatihan menunjukkan perbedaan bermakna $(\mathrm{p}<0,001)$. Hasil analisis paired $t$-test untuk aspek komunikasi diperoleh nilai $\mathrm{p}<0,001$ dan uji Wilcoxon untuk aspek kepemimpinan dan etika diperoleh nilai $\mathrm{p}<0,001$. Simpulan penelitian ini adalah soft skill aspek kepemimpinan mengalami peningkatan skor yang lebih tinggi sebesar 36,4\%, soft skill aspek etika mendapat peningkatan skor $27,2 \%$, sedangkan soft skill aspek komunikasi hanya meningkat $21,0 \%$.
\end{abstract}

Kata Kunci : Kualitas soft skill, manajemen diri, pelatihan 


\title{
Differences in Students Soft Skills Before and After Self Management Training
}

\begin{abstract}
As an educational institution, midwifery high school main goal is to produce a person who has good academic capability as well as non academic capability, and well prepared to work as a good human resource. Several efforts have been done to escalate student soft skill, but still could not reach the target. One of the main keys to strengthen student's soft skill quality is by self management training, to dig out their self personal potency and ability to face any conditions they meet. The aim of this study is to analyze the difference of student's soft skill aspects of communication, leadership and ethics, before and after given a personal management training.An experimental study one group pretest and post-test design was done with one group of pre-test and post-test consisting of total 47 students Midwifery Program D III with low soft skill score (total sampling technique). Measurements aspects of soft skills using a questionnaire.Evaluation will be taken twice, before and after 3 days training. Analizing data showed significant improvement of student's soft skill qualities $(p<0,001)$, using paired t-test for communication aspect and Wilcoxon test for leadership and ethics aspect all shown significant improvement $(\mathrm{p}<0,001)$. Result of this study reveals a significant difference of student's soft skill aspects of communication, leadership and ethics before and after self management training. From those three aspects, the highest improvement was leadership ( $36,4 \%)$, then ethics $(27,2 \%)$ and the lowest was communication aspect $(21,0 \%)$.
\end{abstract}

Keyword: Training, personal management, soft skill quality

\section{Pendahuluan}

Perguruan tinggi sebagai institusi pendidikan yang bertujuan mencetak lulusan yang memiliki kemampuan baik secara akademik maupun non akademik menjadi salah satu pemegang peranan penting dalam menghasilkan sumber daya manusia yang siap kerja. Keberhasilan diterimanya lulusan dalam dunia kerja merupakan tolok ukur keberhasilan perguruan tinggi dalam mengemban amanah masyarakat.

Selama ini terdapat kesenjangan antara dunia pendidikan tinggi dan dunia kerja. Perguruan tinggi memandang lulusan yang mempunyai kompetensi tinggi adalah mereka yang lulus dengan nilai tinggi, sedangkan dunia kerja menganggap bahwa lulusan yang high competence adalah mereka yang mempunyai kemampuan teknis dan sikap yang baik. Orientasi berpikir seperti itulah yang perlu dirubah dikalangan masyarakat bahwa nilai akademik yang bagus dengan Indeks Prestasi Kumulatif (IPK) yang besar belum menjamin kesuksesan di kemudian hari. Keahlian yang dimilikilah yang nantinya akan berperan besar dalam menentukan kesuksesan. ${ }^{1,2}$

STIKes Rajawali merupakan Sekolah Tinggi Ilmu Kesehatan yang berdiri sejak tahun 2008, dari tiga program studi yang diselenggarakan salah satunya adalah Program Studi DIII Kebidanan yang bertujuan untuk menjawab kebutuhan dan tantangan globalisasi dalam hal penyediaan tenaga ahli dibidang kebidanan, yang mampu melaksanakan tugas sesuai dengan kewenangan dan kompetensinya serta dapat bersaing di tingkat nasional dan internasional.

Selain berkomitmen pada pemberian pengajaran yang integral, yaitu dengan mengintegrasikan pelajaran di kelas, laboratorium, dan lahan praktik, Program Studi DIII Kebidanan juga memberikan perhatian khusus pada karakter mahasiswa yakni melalui pembentukan soft skill. Pilar soft skill ini telah dioperasionalkan ke dalam indikator perilaku yang akan dibentuk melalui tenaga pengajar (dosen maupun pembimbing akademik) selama proses belajar mengajar berlangsung. Soft skill ini dinilai secara individual, dengan bobot penilaian sebanyak 15-20\% dari total nilai akhir mahasiswa di setiap mata kuliah yang diikuti.

Terdapat banyak kendala yang dihadapi dalam proses pembentukan, penilaian, dan pencapaian kompetensi soft skill pada diri mahasiswa dalam operasionalisasinya. Berdasarkan hasil penilaian pilar soft skill yang dilakukan oleh dosen pembimbing akademik kepada mahasiswa bimbingannya di akhir semester gasal Tahun Ajaran (TA) 2013/2014 
didapatkan beberapa permasalahan terkait soft skill, diantara-nya dalam aspek komunikasi, masih ada sebagian kecil mahasiswa yang dinilai keterampilan presentasi di kelas kurang, tidak dapat berkomunikasi dengan baik kepada klien saat praktik di Rumah Sakit, Puskesmas atau kepada masyarakat di komunitas, pada saat belajar dengan metode diskusi di dalam kelas masih ditemukan mahasiswa yang tidak aktif baik mendengarkan diskusi maupun mengemukakan pendapat. Demikian halnya dengan komunikasi secara tertulis pada saat pembuatan laporan asuhan kebidanan masih dinilai kurang. Salah satu area kompetensi bidan Indonesia adalah mampu berkomunikasi secara efektif secara verbal dan non verbal dengan pasien/perempuan, keluarganya, masyarakat, sesama profesi, antar profesi, dan stakeholder., Begitu juga dengan profil lulusan DIII Kebidanan yang diharapkan adalah mampu berperan sebagai komunikator untuk memberikan informasi dalam asuhan kebidanan dan pendidikan kesehatan pada masa hamil, nifas, masa remaja, pra konsepsi, pre menopause, yang dibutuhkan oleh keluarga dan masyarakat sesuai dengan kewenangannya.

Dalam aspek kepemimpinan masih didapatkan masalah yaitu beberapa mahasiswa sering terlambat masuk kelas, terlambat mengumpulkan tugas, tidak tahan menghadapi tekanan tugas yang banyak, apabila ditegur karena ada kesalahan hanya diam menerima, tetapi tidak mencari solusi dan berusaha memperbaiki. Hal ini tidak sesuai dengan area kompetensi bidan Indonesia dan profil lulusan yang diharapkan mampu mengelola dan mengevaluasi sumber daya di bawah tanggung jawabnya secara komprehensif dalam melaksanakan pelayanan kebidanan. Bidan dituntut harus mampu menerapkan aspek kepemimpinan dalam organisasi dan manajemen pelayanan kebidanan yaitu Kesehatan Ibu dan Anak (KIA) dan Keluarga Berencana (KB), kesehatan reproduksi, dan kesehatan masyarakat di komunitas dalam praktik kebidanan. ${ }^{4}$

Hal lain yang masih dikeluhkan yaitu aspek etika. Beberapa mahasiswa dinilai pada saat performa praktik di lapangan kurang memperhatikan etika ketika berhadapan dengan klien, berinteraksi dengan karyawan, dan kurang perhatian kepada klien. Hal ini tidak sesuai dengan profil lulusan DIII Kebidanan harus mempunyai sikap menjunjung tinggi nilai kemanusiaan dalam menjalankan praktik kebidanan berdasarkan agama, moral dan filosofi, kode etik profesi, serta standar kebidanan. Salah satu tugas bidan adalah harus memperhatikan kaidah/norma yang berlaku di masyarakat, menjunjung tinggi moral dan etika, taat dan sadar hukum, menghargai pelanggan dan teman sejawat, serta bekerja sesuai dengan standar profesi. ${ }^{3,5}$

Permasalahan tersebut muncul salah satunya dilatarbelakangi oleh minimnya program khusus dari pendidikan tinggi terkait pembekalan soft skill untuk mahasiswa. Program pembekalan soft skill belum dirancang secara terstruktur, melainkan berjalan secara alamiah melalui proses belajar yang berorientasi pada keaktifan siswa (di kelas) dan pengalaman untuk praktik langsung di lapangan. Soft skill tersebut diasumsikan akan terbentuk dengan sendirinya seiring dengan tuntutan tugas yang harus disesuaikan oleh mahasiswa.

Salah satu cara pengayaan untuk meningkatkan kualitas soft skill mahasiswa yaitu dengan konsep manajemen diri sehingga diajarkan mengenai pengelolaan waktu, komunikasi secara efektif, membuat keputusan, mendelegasikan, dan mengelola segala kondisi yang terjadi. Jadi, untuk memulai proses pengembangan diri adalah dengan menyadari beberapa teknik pengembangan diri untuk mengelola proses pembentukan soft skill. ${ }^{2,6}$

Secara pragmatis program pelatihan memiliki dampak positif baik bagi individu maupun organisasi. Profil kapabilitas individual berkaitan dengan skill yang diperoleh dari pelatihan. Seiring dengan penguasaan keahlian atau keterampilan yang diterima individu akan meningkat. Pada akhirnya hasil pelatihan akan membuka peluang bagi pengembangan karier individu dalam organisasi. Dalam konteks seperti ini, peningkatan karir atau promosi ditentukan oleh pemilikan kualifikasi skill. Adapun alasan penyusunan program pelatihan hendaknya dilakukan untuk mengatasi masalah tertentu yang akan memberi kontribusi dalam mencapai tujuannya.

Dalam Buku Evaluating Training programs dijelaskan hasil evaluasi yang dilakukan dalam mengukur pengetahuan dan/atau sikap sebelum dilakukan program pelatihan dan setelah dilakukan program pelatihan terdapat perbedaan 
hasil. Terdapat peningkatan pengetahuan dan/atau sikap setelah dilakukan program pelatihan. ${ }^{7,8}$

Penelitian yang dilakukan pada mahasiswa Fakultas Psikologi Universitas Airlangga, didapatkan hasil ada perbedaan pemberian pelatihan komunikasi efektif untuk meningkatkan efikasi diri mahasiswa. Pemberian pelatihan merupakan salah satu sumber untuk mengembangkan efikasi diri seseorang. Pelatihan keterampilan komunikasi dapat meningkatkan atau mengembangkan soft skill seseorang dalam aspek komunikasinya. ${ }^{9}$

Hasil penelitian menunjukkan pelatihan kepemimpinan transformasional merupakan salah satu bentuk intervensi yang dapat meningkatkan persepsi perilaku kepemimpinan atasan dan motivasi kerja bawahan. ${ }^{10}$ Pelatihan manajemen diri hanyalah salah satu cara untuk meningkatkan kualitas soft skill mahasiswa peserta didik, masih banyak cara lain yang bisa dilakukan baik oleh lembaga ataupun mahasiswa itu sendiri.

Penelitian ini bertujuan untuk melihat perbedaan kualitas soft skill aspek komunikasi, kepemimpinan, dan etika mahasiswa Program Studi Kebidanan STIKes Rajawali Bandung sebelum dan sesudah diberikan pelatihan manajemen diri.

\section{Subjek Penelitian}

Subjek dalam penelitian ini adalah mahasiswa Program Studi DIII Kebidanan yang teridentifikasi nilai soft skill rendah berjumlah 47 mahasiswi.

\section{Kriteria Inklusi}

Berdasarkan rekomendasi dan hasil penilaian dari pembimbing akademik mengenai soft skill mahasiswa yang kurang meliputi:
a. Kemampuan komunikasi yang kurang baik lisan maupun tulisan
b. Tidak dapat melakukan presentasi dengan baik
c. Pasif pada saat kegiatan diskusi di kelas
d. Sering terlambat mengumpulkan tugas
e. Sering terlambat masuk kelas
f. Etika kurang
2. Kriteria Eksklusi
a. Mahasiswa yang tidak hadir
b. Mahasiswa dalam keadaan sakit

\section{Metode}

Metode yang digunakan dalam penelitian ini adalah eksperimental dengan rancangan one group pre-post test design. Penelitian ini bertujuan untuk mengetahui apakah terdapat Perbedaan kualitassoft skill aspek komunikasi, kepemimpinan, dan etika mahasiswa sebelum dan sesudah dilakukan pelatihan manajemen diri.

Kelompok perlakuan dalam penelitian ini adalah satu kelompok subjek dengan satu eksperimental (treatment). Satu kelompok tersebut berfungsi sebagai kelompok eksperimental sekaligus sebagai kelompok kontrol. Pelatihan diberikan oleh tenaga terlatih yang menguasai dalam bidang pelatihan manajemen diri. Pelatihan manajemen diri ini menggunakan modul yang menggunakan konsep dasar manajemen diri, komunikasi efektif, etika dalam kebidanan, materi kedisiplinan, materi kepemimpinan, dan mengenal latihan baris berbaris. Metode yang digunakan dalam pelatihan ini, yaitu metode ceramah, diskusi, role play, permainan, dan renungan malam.

Pengukuran aspek soft skill sebelum pelatihan manajemen diri dilakukan untuk menilai aspek soft skill komunikasi, kepemimpinan, dan etika mahasiswa menggunakan data primer, penilaian ketiga aspek soft skill di atas dilakukan oleh responden sendiri menggunakan jenis pelaporan diri (self-report). Setelah dilakukan treatment selama tiga hari kemudian dilakukan penilaian kembali ketiga aspek soft skill untuk melihat efek dari treatment. Adapun waktu penilaian dilakukan setelah 3 bulan dilakukan treatment. Waktu pengukuran setelah treatment mengadopsi penelitian Gintner \& Poret (2001) bahwa setelah mengikuti pelatihan manajemen diri dan dilakukan follow up setelah sepuluh minggu diadakan post-test, subjek mengalami peningkatan keyakinan diri dan mampu mengantisipasi tekanan atas suatu resiko dalam kerja dibandingkan dengan subjek yang tidak diberikan program pelatihan manajemen diri.

Jenis data yang digunakan dalam penelitian ini adalah data sekunder yang diperoleh dari data kemahasiswaan dan data primer yang diperoleh langsung dari responden saat penelitian dilakukan. Data primer berupa kuesioner yang bersifat tertutup yang dirancang berdasarkan studi literatur dari beberapa ilmu terkait dan 
dikembangkan berdasarkan keterkaitan variabelvariabel yang di adaptasi dari teori Green. ${ }^{11}$ Sebelum diaplikasikan kepada subjek, instrumen yang dibuat sudah dievaluasi kualitasnya yang ditunjukkan oleh properti psikometris instrumen tersebut dari data uji coba instrumen soft skill. Pernyataan yang telah disusun dengan alternatif jawaban meliputi : Sangat Setuju (SS), Setuju $(\mathrm{S})$, Netral (N), Tidak Setuju (TS) dan Sangat Tidak Setuju (STS). Isi kuesioner untuk pre-test dan post-test adalah sama. Adapun pemberian skor didasarkan pada jawaban responden dengan mempertimbangkan jenis pertanyaannya sebagai berikut:

\section{Tabel 1 Skoring Kuesioner}

\begin{tabular}{lclc}
\hline \multicolumn{2}{c}{ Item Positif } & \multicolumn{2}{c}{ Item Negatif } \\
\hline \multicolumn{1}{c}{ Jawaban } & Skor & \multicolumn{1}{c}{ Jawaban } & Skor \\
\hline Sangat Setuju & 5 & Sangat Setuju & 1 \\
Setuju & 4 & Setuju & 2 \\
Netral & 3 & Netral & 3 \\
Tidak setuju & 2 & Tidak setuju & 4 \\
Sangat tidak & 1 & Sangat tidak & 5 \\
setuju & & setuju & \\
\hline
\end{tabular}

Uji coba instrumen dilakukan terhadap 20 orang responden yang karakteristiknya hampir sama dengan sampel penelitian yaitu mahasiswa DIII Kebidanan POLTEKES TNI AU Ciumbuleuit Bandung. Berdasarkan hasil uji diperoleh pertanyaan dalam kuesioner yang valid dengan $r$ hitung 23,61 sebanyak 45 pertanyaan, sedangkan dari hasil uji reliabilitas diperoleh nilai Cronbach Alpha sebesar 0,728 sehingga kuesioner dinyatakan reliabel.

Pengumpulan data dengan kuesioner dikumpulkan 1 minggu menjelang pelatihan manajemen diri (pre-test), 3 bulan setelah pelatihan manajemen diri (post-test)

\section{Gambar 1 Rancangan Penelitian}

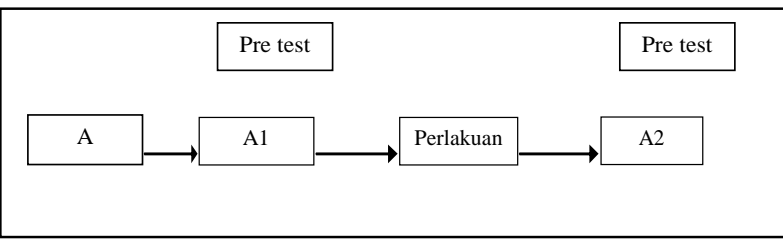

Keterangan :

A : Pemilihan Kelompok

A1 : Pengukuran aspek soft skill pada kelompok sebelum perlakuan

A2 : Pengukuran aspek soft skill pada kelompok setelah perlakuan.

Teknik analisis data dengan analisis bivariabel menggunakan uji statistik yaitu:

1) Uji Mann-Whitney untuk uji variabel perancu (kedudukan dalam keluarga, bentuk keluarga) pada kelompok perlakuan.

2) Uji normalitas data yang digunakan dalam penelitian ini adalah uji Shapiro Wilk. Kemaknaan hasil uji normalitas data ditentukan berdasarkan nilai $p>0,05$.

Uji $\mathrm{t}$ berpasangan digunakan untuk uji perbedaan rata-rata dari variabel yang diteliti menggunakan uji parametrik yaitu uji $t$ berpasangan sebelum dan setelah dilakukan pelatihan dengan asumsi data berdistribusi normal. Untuk data yang distribusi datanya tidak normal menggunakan uji non parametrik yaitu uji Wilcoxon.

\section{Hasil}

Hasil uji normalitas data variabel soft skill aspek komunikasi sebelum pelatihan berdistribusi normal sehingga uji statistik yang digunakan adalah uji parametrik yaitu uji $t$ berpasangan. Hasil uji normalitas data variabel soft skill aspek kepemimpinan dan etika tidak berdistribusi normal sehingga uji statistik yang digunakan adalah uji non parametrik yaitu uji Wilcoxon. Selengkapnya dapat dilihat pada tabel 2. 
Tabel 2 Perbedaan Kualitas Aspek soft Skill Mahasiswa Sebelum dan Sesudah Pelatihan

\begin{tabular}{|l|c|c|c|c|}
\hline \multirow{2}{*}{$\begin{array}{c}\text { Kualitas Soft skill } \\
\text { Skala 100) }\end{array}$} & $\bar{x}(\mathrm{SD})$ & Median & Rentang & \multirow{2}{*}{ Nilai $\rho$} \\
\cline { 2 - 5 } & \multicolumn{4}{|c|}{} \\
\hline Aspek Komunikasi & $47,8(13,2)$ & 45 & $22,5-82,5$ & $<0,001^{*}$ \\
\hline Pre tes & $60,8(9,9)$ & 62,5 & $37,5-87,5$ & \\
\hline Post tes & $57,0(11,7)$ & 55 & $37,5-77,5$ & $<0,001^{* *}$ \\
\hline Aspek Kepemimpinan & $73,0(9,6)$ & 75 & $52,5-87,5$ & \\
\hline Pre tes & $46,4(7,4)$ & 47,5 & $30,0-60,0$ & $<0,001^{* *}$ \\
\hline Post tes & $59,9(15,2)$ & 57,5 & $25,0-90,0$ & \\
\hline Aspek Etika &
\end{tabular}

Ket $: \rho^{*}:$ Nilai rerata (SD) dengan uji t

$\rho^{* *}$ : Nilai median dan rentang dengan uji Wilcoxon

Berdasarkan analisis dengan uji $\mathrm{t}$ berpasangan pada variabel soft skill aspek komunikasi mahasiswa Program Studi DIII Kebidanan sebelum dan sesudah pelatihan menunjukkaan perbedaan yang bermakna $(\mathrm{p}<0,001)$.
Berdasarkan analisis dengan uji Wilcoxon pada variabel soft skill aspek kepemimpinan dan etika mahasiswa program studi DIII kebidanan sebelum dan sesudah diberikan pelatihan menunjukkan perbedaan yang bermakna $(\mathrm{p}<0,001)$.

\section{Tabel 3 Perbandingan Kualitas Aspek Soft Skill Mahasiswa DIII Kebidanan Sebelum dan Sesudah Pelatihan}

\begin{tabular}{|c|c|c|c|c|}
\hline \multirow{2}{*}{$\begin{array}{l}\text { Kualitas Soft skill } \\
\quad \text { (Skala 100) }\end{array}$} & \multicolumn{2}{|c|}{ Pengamatan } & \multirow{2}{*}{ Nilai $\rho$} & \multirow{2}{*}{$\begin{array}{c}\text { Peningkatan } \\
(\%)\end{array}$} \\
\hline & Pre & Post & & \\
\hline Aspek komunikasi & $47,8(13,2)$ & $60,8(9,9)$ & $<0,001$ & $21,0 \%$ \\
\hline Aspek kepemimpinan & $55,0(37,5-77,5)$ & $75,0(52,5-87,5)$ & $<0,001$ & $36,4 \%$ \\
\hline Aspek etika & $47,5(30,0-60,0)$ & $57,5(25,0-90,0)$ & $<0,001$ & $27,2 \%$ \\
\hline
\end{tabular}

\section{Pembahasan}

Soft skill aspek komunikasi berdasarkan hasil penelitian diperoleh nilai $p<0,001$ dan peningkatan skor sebanyak $21 \%$ artinya terdapat perbedaan sebelum dan sesudah dilakukan pelatihan manajemen diri. Pelatihan manajemen diri meningkatkan motivasi kemampuan mahasiswa dalam aspek komunikasi dimana dalam pelatihan manajemen diri dilakukan kegiatan-kegiatan yang bertujuan untuk mengolah cara berkomunikasi secara efektif. Hal ini didukung oleh penelitian yang dilakukan dilakukan pada mahasiswa Fakultas Psikologi Universitas Airlangga bahwa ada perbedaan pemberian pelatihan komunikasi efektif untuk meningkatkan efikasi diri mahasiswa. Pemberian pelatihan juga merupakan salah satu sumber untuk mengembangkan efikasi diri seseorang. Pelatihan keterampilan komunikasi dapat meningkatkan atau mengembangkan soft skill seseorang dalam aspek komunikasinya. ${ }^{9}$

Peningkatan kualitas soft skill aspek komunikasi dalam penelitian ini merupakan peringkat kedua setelah aspek soft skill kepemimpinan dan skor peningkatannya belum begitu baik bila dibandingkan dengan aspek soft skill kepemimpinan. Hal ini sangat dimungkinkan adanya hambatan dari diri sendiri berupa latar belakang budaya, lingkungan sosial, kurang percaya diri karena ketika seseorang memiliki keyakinan yang kuat atau kepercayaan diri yang tinggi akan keterampilan yang 
dimilikinya, diharapkan seseorang tersebut mampu menjalankankemampuan tersebut lebih baik. $^{12}$

Soft skill aspek kepemimpinan berdasarkan hasil penelitian diperoleh $p<0,001$ dan peningkatan skor sebesar $36,4 \%$, artinya terdapat perbedaan antara sebelum dan sesudah dilakukan pelatihan manajemen diri. Pelatihan manajemen diri memberikan dampak yang baik terhadap peningkatan soft skill aspek kepemimpinan mahasiswa. Pelatihan manajemen diri ini dapat meningkatkan kepercayaan diri, kemampuan untuk menguasai diri dan motivasi. Motivasi merupakan faktor penggerak dalam diri seseorang yang dapat mengarahkan perilaku. Dengan kemampuan untuk mengarahkan perilaku diri akan mengarahkan mahasiswa untuk mengetahui cara memimpin orang banyak atau masyarakat sebagai bidan. Hal ini bertolak belakang dengan penelitian yang dilakukan oleh Humaira dimana hasil penelitian menunjukkan pelatihan kepemimpinan transformasional merupakan salah satu bentuk intervensi yang dapat meningkatkan persepsi perilaku kepemimpinan atasan dan motivasi kerja bawahan. $^{10}$

Kepemimpinan dalam kebidanan sacara garis besar memfokuskan diri pada sifat, perilaku, etika dan hukum, tanggung jawab, keterampilan serta bertakwa kepada Tuhan Yang Maha Esa. Menurut pengalaman bidan yang berhasil mengelola praktik kebidanannya dari organisasi sederhana berkembang menjadi organisasi yang besar atau rumah sakit, disimpulkan mereka berhasil menjadi manager yang mampu meningkatkan pelayanannya dan mengembangkan organisasinya dengan dasar ketekunan, keuletan, kerja keras, dan mau berubah ke arah yang lebih baik serta bertakwa kepada Tuhan Yang Maha Esa. ${ }^{11}$

Soft skill aspek etika berdasarkan hasil penelitian diperoleh nilai $p<0,001$ dan peningkatan skornya sebanyak $27,2 \%$, artinya terdapat perbedaan antara sebelum dan sesudah pelatihan manajemen diri. Pelatihan manajemen diri yang telah dilakukan memberikan dampak yang baik terhadap peningkatan soft skill etika mahasiswa. Pelatihan manajemen diri membentuk karakter dan kepribadian mahasiswa, hal ini terjadi dimungkinkan karena dalam pelatihan manajemen diri dilakukan kegiatan yang mengutamakan kerjasama sehingga tercipta rasa saling menghargai, menghormati antar sesama. Rendahnya skor peningkatan etika dalam pelatihan ini dimungkinkan oleh beberapa faktor yang menyebabkan perilaku mahasiswa yang tidak etis, diantaranya mahasiswa yang memiliki kemampuan kognitif yang rendah yang menyebabkan tingkat penerimaan yang kurang baik, adanya pengaruh teman, keluarga ataupun norma sosial yang lebih menentukan dalam memengaruhi perilaku mahasiswa. Adanya ethical dilema yaitu situasi yang menyebabkan adanya pilihan-pilihan yang muncul yang berpotensi menghasilkan perilaku yang tidak dapat diterima oleh personal, organisasi, dan profesi.

Pelatihan manajemen diri yang dilakukan dapat memberikan dampak terhadap mahasiswa untuk mengendalikan hal-hal yang berlebihan dalam pengambilan keputusan maupun perilakunya, yang dapat digambarkan sebagai seperangkat strategi kognitif dan perilaku yang membantu mahasiswa menstruktur lingkungannya, membentuk motivasi diri, dan memfasilitasi perilaku yang tepat khususnya dalam mengantisipasi tekanan-tekanan yang dihadapi di kampus dan mengelolanya serta dapat mengendalikan diri dengan baik sehingga mahasiswa dapat menjaga dan mengembangkan perilaku etikanya.

\section{Simpulan}

Terdapat perbedaan kualitas soft skill aspek komunikasi, kepemimpinan dan etika mahasiswa Program Studi DIII Kebidanan STIKes Rajawali Bandung antara sebelum dan setelah dilakukan pelatihan manajemen diri.

Dari ketiga aspek kualitas soft skill yang diteliti soft skill aspek kepemimpinan yang mengalami skor peningkatan yang yaitu $36,4 \%$, soft skill aspek etika mendapat urutan skor peningkatan kedua yaitu $27,2 \%$ sedangkan soft skill aspek komunikasi hanya $21 \%$.

\section{Daftar Pustaka}

1. Sub Direktorat KPS. Buku panduan pengembangan kurikulum berbasis kompetensi pendidikan tinggi (Sebuah alternatif penyusunan kurikulum). Jakarta: Direktorat Akademik Direktorat Jenderal Pendidikan Tinggi; 2008.

2. Sailah. Pengembangan soft skill di Perguruan Tinggi. Jakarta: [diunduh 06 Maret 2013]. Tersedia dari: http://isailah.50webs.com/Buku\%20pengembangan\%20 softskills\%202008.pdf. 
3. Ikatan Bidan Indonesia (IBI) dan Asosiasi Institusi Pendidikan Kebidanan Indonesia (AIPKIND). Standar Nasional Pendidikan Diploma Iii Kebidanan Indonesia (Unduh 5 Juni 2014) Tersedia dari: http:// hpeq. dikti. go.id/v2/images/Produk/19.4.1DRAFT-STANDARPENDIDIKAN-DIPLOMA-III-KEBIDANA-12-Sept2012.pdf.

4. Peraturan Menteri Kesehatan Republik Indonesia No. 149 pasal 8 tahun 2010 (unduh 11 September 2013) tersedia dari:

http://www.hukor.depkes.go.id/up_prod_permenkes/PM K\%20No.\%20HK.02.02149\%20ttg\%20Izin\%20Dan\%2 0Penyelenggaraan\%20Praktik\%20Bidan.pdf

5. Kementerian Kesehatan RI. Kurikulum Inti Pendidikan Diploma Kebidanan. Jakarta: Badan Pengembangan SDM Kesehatan Pusat pendidikan dan Pelatihan Tenaga Kesehatan; 2011.

6. HNC Management. Management: Developing Self Management Skills. Midlothian: Scottish Qualifications Authority; 2007.

7. Widhiarso, Wahyu. Evaluasi soft skills dalam pembelajaran dalam seminar dan saresehan "Evaluasi pembelajaran mata kuliah umum kependidikan"; [14 Februari 2009]; FIP UNY; UGM: Fakultas Psikologi; 2009. h. 1-2.
8. Kirkpatrick, D. L. Evaluating Training Programs:the four levels.USA; berrett-koehler publishers; 2005.

9. Wardani, Deta. S. K. Pengaruh peningkatan komunikasi efektif untuk meningkatkan efikasi diri mahasiswa. Jurnal Psikologi Pendidikan dan Perkembangan. 2012. [14 Maret 2013]; vol 1 (2). Tersedia dari: http://journal.unair.ac.id/filerPDF/110710233_3v.pdf

10. Humaira, Layyina. Pelatihan kepemimpinan transformasional untuk meningkatkan persepsi perilaku kepemimpinan atasan \& motivasi kerja bawahan (studi karyawan cabang Y PT.X). 2012. [10 Agustus 2014]. Tersedia dari :

http://lib.ui.ac.id/file?file=digital/20309235.\%20Pelatiha n\%20kepemimpinan.pdf

11. Nawangsari, Sunjaya DK, Wirakusumah FF. Hubungan penguasaan kompetensi asuhan persalinan normal (APN) dengan pengetahuan dan sikap bidan dalam pelaksanaan pertolongan persalinan normal di kabupaten Jombang, Jawa Timur. Maj Obstet Ginekol Indones. 2009;33(1):3-7.

12. Covey, S. R. The 7th habits of highly effective people (Kebiasaan manusia yang efektif). Jakarta Barat: Bina Aksara; 1997. 